\title{
PENGARUH STRATEGI PEMBELAJARAN DAN LOCUS OF CONTROL TERHADAP HASIL BELAJAR EKONOMI
}

\author{
Christina Yantha Sari Situmeang ${ }^{1}$ dan Keysar Panjaitan ${ }^{2}$ \\ SMA Methodis1 dan SMA Kalam Kudus Medan ${ }^{1}$ dan Universitas Negeri Medan ${ }^{2}$ \\ christianyantha@yahoo.com ${ }^{l}$
}

\begin{abstract}
Abstrak: Penelitian ini bertujuan untuk mengetahui: perbedaan hasil belajar Ekonomi antara siswa yang dibelajarkan dengan menggunakan Strategi Genius Learning dan Strategi Ekspositori, mengetahui perbedaan hasil belajar siswa yang memiliki Locus of Control Internal dan Locus of Control Eksternal, interaksi antara penggunaan Strategi pembelajaran dan Locus of Control dalam mempengaruhi hasil belajar Ekonomi siswa. Metode penelitian menggunakan metode quasi eksperimen dengan disain penelitian faktorial 2x2, sedangkan teknik analisis data menggunakan ANAVA dua jalur pada taraf signifikansi $\alpha=0.05$. Syarat ANAVA adalah data berdistribusi normal dengan lilifors dan data harus memiliki varians populasi homogen dengan uji bartlett dan uji fisher. Hasil penelitian diperoleh: hasil belajar ekonomi siswa yang belajarkan dengan menggunakan Strategi Pembelajaran Genius Learning lebih tinggi dibandingkan dengan Strategi Ekspositori, hasil belajar ekonomi siswa yang memiliki Locus of Control internal lebih tinggi dibandingkan Locus of Control eksternal dan terdapat interaksi antara penggunaan Strategi pembelajaran dengan Locus of Control dalam mempengaruhi hasil belajar ekonomi.
\end{abstract}

Kata Kunci: strategi pembelajaran, locus of control, hasil belajar ekonomi

Abstract: This study aims to determine: differences in learning outcomes of Economics among the students that learned by using strategies Genius Learning and Strategies Expository, determine differences in learning outcomes of students who have the Locus of Control and Internal Locus of Control External, the interaction between the use of learning strategies and Locus of Control in influencing student learning outcomes Economics. The research method using quasi-experimental design with a $2 \times 2$ factorial study, while data analysis techniques using ANOVA two lanes at significance level $\alpha=0: 05$. Terms ANOVA is the normal distribution of data with lilifors and data must have a homogeneous population variance with Bartlett test and fisher test. The results were obtained: the results of studying economics students who are teaching by using the Learning Strategies Genius Learning higher than Strategies Expository, the results of studying economics student who has Locus of Control internal higher than Locus of Control external and there is an interaction between the use of learning strategies with Locus of Control in the economy affect learning outcomes.

Keywords: learning strategies, locus of control, the results of the economic study

\section{PENDAHULUAN}

Pelajaran ekonomi adalah salah satu mata pelajaran pokok yang mulai diperkenalkan mulai dari tingkat SD dan semakin berkembang pada tingkat SMP hingga Perguruan tinggi. Ekonomi merupakan pengetahuan yang memiliki aspek pemahaman konsep, penalaran, serta aspek pemecahan masalah yang diperlukan dalam zaman teknologi sekarang ini. Oleh sebab itu ekonomi memegang peranan penting dalam dunia pendidikan yang harus dipelajari dan dikuasai oleh setiap peserta didik dengan harapan agar siswa dapat mencapai hasil belajar yang diharapkan. Kualitas pendidikan ekonomi di Indonesia secara umum belum sesuai dengan hasil yang diharapkan. Ini ditandai dengan rendahnya nilai ekonomi siswa seperti yang terjadi di SMA Methodist 1 dan SMA Kalam Kudus Medan. Yang dilihat dari rata-rata nilai UAN yang masih mencapai angka 5,0 melalui hasil wawancara di sekolah tersebut. Nilai ekonomi siswa yang rendah juga disebabkan oleh anggapan siswa terhadap mata pelajaran ekonomi itu sendiri. Banyak siswa yang menganggap ekonomi adalah pelajaran yang rumit. Sebelum mengerjakan soal-soal ekonomi, 
kebanyakan siswa sudah menganggap soalnya sulit, dan akhirnya siswa tidak bisa mengerjakan soal tersebut sama sekali. Sebelum guru mengajar, siswa sudah merasa bosan dan menganggap tidak akan bisa mengerti apa yang guru jelaskan, dan akhirnya siswa tidak memahami apa yang guru ajarkan.

Sampai saat ini pendidikan kita masih didominasi oleh anggapan bahwa pelajaran itu harus dihafal, berfokus kepada guru yang menjadi sumber utama ilmu dan ceramah adalah metode yang selalu diterapkan. Siswa hanya menerima informasi yang diberikan guru sehingga siswa kurang diberdayakan. Kegiatan belajar ini hanya mengakibatkan siswa menjadi kurang mampu memahami makna belajar dan kurang mampu untuk mengembangkan kemampuan dirinya, serta hasil belajar yang diperoleh kurang memuaskan.

Gunawan (2006) mengungkapkan, "Dalam menerapkan strategi pembelajaran Berbasis Genius Learning, kita berangkat dengan satu keyakinan dan pengharapan bahwa apabila setiap anak didik dapat dimotivasi dengan tepat dan diajar dengan cara yang benar yang menghargai keunikan mereka maka mereka semua dapat mencapai suatu hasil pembelajaran yang maksimal".

Dalam menerapkan strategi pembelajaran Berbasis Genius Learning ini anak didik ditempatkan sebagai pusat dari proses pembelajaran, anak didik tidak menjadi obyek pendidikan melainkan sebagai subyek pendidikan. Selain faktor -faktor dari guru, faktor yang berasal dari dalam diri siswa juga berpengaruh dalam proses pembelajaran.

Selain strategi pembelajaran yang digunakan oleh guru, nilai ekonomi siswa yang rendah juga disebabkan oleh anggapan siswa terhadap mata pelajaran ekonomi itu sendiri. Banyak siswa yang menganggap ekonomi adalah pelajaran yang rumit maka siswa membutuhkan dorongan dalam belajar yaitu Locus Of Control. Locus Of Control merupakan konsep psikologi yang menggambarkan apakah individu tersebut mampu melihat dirinya (internal) dan mampu mengadakan kontrol terutama untuk orang dan peristiwa di luar dirinya (eksternal). Eksternal atau lokus kontrol negatif adalah orang yang mempersiapkan perilaku dan lingkungannya sebagai akibat dari keadaan di luar dirinya, misalnya karena keberuntungan, kesempatan, orang yang berkuasa, otoritas dan sebagainya. Berbagai faktor baik dari dalam maupun dari luar diri seseorang merupakan penyebab terjadinya suatu keberhasilan maupun kegagalan yang diperolehnya. Rotter dalam Taylor (1997) mengatakan bahwa Locus Of Control adalah bagaimana seseorang sadar tentang diri mereka sesuai dengan kontrolnya. Internal bila kesadaran pada diri sendiri dan eksternal bila kesadaran berasal dari orang lain diluar dirinya. Locus Of Control merupakan salah satu variabel kepribadian yang didevenisikan sebagai keyakinan individu terhadap mampu tidaknya mengontrol nasib dirinya.

Menurut Goleman (1996) bahwa kesuksesan seseorang 20\% ditentukan oleh IQ dan sekitar $80 \%$ dipengaruhi faktor lain yang meliputi kontrol diri Locus of Control, percaya diri, sikap, empati dan kecerdasan sosial. Hal ini berarti bahwa individu akan sukses apabila lebih percaya diri, sadar akan kemampuan diri sendiri, selalu mengadakan kontrol diri sehingga dapat menyesuaikan dengan situasi dan kondisi dimana dia berada termasuk meraih prestasi.

Gredler dalam Warsita (2008) mengemukakan konsep belajar sebagai suatu upaya atau proses perubahan tingkah laku seseorang sebagai akibat interaksi dengan peserta didik dengan berbagai sumber belajar yang ada disekitarnya. Salah satu tanda seseorang telah belajar adalah adanya perubahan tingkah laku dalam dirinya. Perubahan tingkah laku tersebut meliputi perubahan pengetahuan (kognitif), keterampilan (psikomotor), dan nilai sikap (afektif). Dengan demikian belajar adalah proses orang memperoleh berbagai kecakapan, keterampilan dan sikap.

Menurut Gagne (1985) hasil belajar dapat diartikan sebagai kapasitas atau kemampuan yang dapat diperoleh dari proses belajar yang dikelompokkan kedalam lima kategori, yaitu: (1) kognitif, (2) informasi verbal, (3) strategi kognitif, (4) keterampilan motorik, dan (5) sikap. Hal yang hampir senada tentang pengertian hasil belajar juga dikemukakan oleh Dick and Raiser (1989) bahwa hasil belajar adalah kemampuankemampuan yang dimiliki siswa sebagai hasil kegiatan pembelajaran. Mereka membedakan hasil belajar atas empat macam, yaitu: pengetahuan, keterampilan, intelektual, keterampilan motorik dan sikap.

Perubahan tingkah laku yang diperoleh melalui hasil belajar dapat dilihat pada beberapa ciri-ciri, yaitu (1) terbentuknya tingkah laku yang berupa kemampuan aktual dan potensial, (2) kemampuan ini berlaku dalam waktu yang relatif lama, dan (3) kemampuan baru ini 
diperoleh melalui usaha (Snelbecker, 1974). Sementara Romizowski (1981) juga menyatakan hasil belajar berupa keterampilan dibedakan atas empat kategori, yaitu keterampilan berfikir, aksi, reaksi serta berinteraksi.

Lebih lanjut Bloom mengemukakan tentang hasil belajar yang direvisi Anderson (2001) menyatakan hasil belajar dibagi dalam tiga kawasan/ranah, yaitu: (1) kawasan kognitif yang berisi perilaku-perilaku yang menekankan aspek intelektual, seperti pengetahuan, pengertian, dan keterampilan berpikir, (2) kawasan afektif yang berisi perilaku-perilaku yang menekankan aspek perasaan dan emosi, seperti minat, sikap, apresiasi, dan cara penyesuaian diri, dan (3) kawasan psikomotor berisi perilaku-perilaku yang menekankan aspek keterampilan motorik seperti tulisan tangan, mengetik, berenang, dan mengoperasikan mesin. Ilmu ekonomi adalah suatu ilmu yang sudah cukup lama berkembang sebagai satu bidang ilmu pengetahuan Analisis dalam ilmu ekonomi dapat dibedakan kepada tiga golongan: (1) ekonomi deskriptif, yaitu menggambarkan keadaan yang sebenarnya berlaku dalam ekonomi, (2) teori ekonomi yaitu, memberikan gambaran umum mengenai kegiatan ekkonomi yang berlaku dan sifat hubungannya diantara berbagai variabal ekonomi, (3) ekonomi terapan/ teori kebijakan ekonomi, yaitu analisis mengenai bagaimana masalah ekonomi diatasi. Analisis dalam ekonomi tidak terbatas kepada uraian deskriptif mengenai kegiatan ekonomi yang berlaku. Teori ekonomi biasanya menggunakan empat analisis yaitu (1) uraian mengenai sifat hubungan diantara dua atau beberapa variabel ekonomi, (2) data yang berbentu angka-angka yang menggambarkan sifat hubungan tersebut, (3) gambaran secara grafik mengenai sifat hubungan Strategi

berhubungan dengan cara menyampaikan pesan dalam pembelajaran. Strategi meliputi sifat, ruang lingkup, dan rangkaian kejadian yang mengandung pengalaman belajar. Strategi harus memperhitungkan tujuan yang telah ditetapkan dan mempertimbangkan karakteristik siswa. Strategi pembelajaran adalah rencana untuk mencapai tujuan pembelajaran yang dikembangkan dari metode-metode dan teknikteknik yang akan membantu siswa mencapai tujuan pembelajarannya. (Gerlach \& Ely, 1980).

Menurut Kirby (1984) strategi

sesungguhnya merupakan metode

untuk menyelesaikan tugas-tugas, atau secara umum untuk mencapai tujuan. Strategi pembelajaran adalah metode untuk mencapai tujuan pembelajaran. Dick \& Carey (2005) menjelaskan strategi pembelajaran sebagai satu set materi dan prosedur pembelajaran yang digunakan secara bersama-sama untuk mencapai hasil belajar siswa. David seperti yang dikutip Sanjaya (2008) mendefinisikan strategi pembelajaran sebagai perencanaan yang berisi tentang rangkaian kegiatan yang didesain untuk mencapai tujuan pendidikan tertentu.

Prawiradilaga (2008) mendefinisikan strategi pembelajaran sebagai upaya yang dilakukan oleh perancang dalam menentukan teknik penyampaian pesan, penentuan metode dan media, alur isi pelajaran serta interaksi antara pengajar dan peserta didik. Strategi pembelajaran menurut Miarso (2007) merupakan pendekatan menyeluruh pembelajaran dalam suatu sistem pembelajaran, yang berupa pedoman umum dan kerangka kegiatan untuk mencapai tujuan umum pembelajaran, yang dijabarkan dari pandangan falsafah atau teori

belajar tertentu.

Terdapat prinsip-prinsip umum penggunaan strategi pembelajaran (Sanjaya, 2008), yaitu: (1) berorientasi pada tujuan, yaitu dalam pembelajaran tujuan merupakan komponen yang utama, keberhasilan suatu strategi tergantung pada tercapainya tujuan, (2) aktivitas, strategi pembelajaran harus dapat mendorong aktivitas siswa (3) individualitas, strategi pembelajaran pada hakikatnya ingin mencapai perubahan prilaku setiap siswa dan (4) integritas, strategi pembelajaran harus dapat mengembangkan seluruh aspek kepribadian siswa secara terintegrasi.

Dasar strategi pembelajaran Berbasis Genius Learning adalah Accelerated Learning atau cara belajar yang dipercepat, berkembang sejak tahun 1970 yang merupakan hasil temuan Dr. Lozanov. Accelerated Learning adalah salah satu cara belajar alamiah yang menggugah sepenuhnya kemampuan belajar para pelajar. Tujuannya sama, yaitu bagaimana membuat proses pembelajaran menjadi efisien, efektif, dan menyenangkan. Hanya saja strategi pembelajaran Berbasis Genius Learning telah memasukkan dan mempertimbangkan kondisi masyarakat Indonesia secara umum.

Menurut Walberg dan Greenberg (dalam DePorter, 2004), lingkungan sosial adalah penentu psikologis utama yang mempengaruhi belajar akademis. Suasana atau keadaan ruangan menunjukkan arena belajar 
yang dipengaruhi emosi. Penelitian menunjukkan bahwa para siswa menyebut kualitas hubungan mereka dengan guru sebagai faktor paling utama dalam kaitannya dengan kenyamanan dalam belajar atau tidak.

Penciptaan lingkungan belajar yang menyenangkan dan pembinaan hubungan yang harmonis antara guru dan siswa diharapkan mampu memunculkan emosi yang positif bagi siswa. Emosi yang positif ini sangat mempengaruhi keberhasilan siswa dalam belajar, karena berkaitan dengan cara kerja otak manusia. Lingkungan yang banyak memberikan tekanan mental dan stres akan sangat menghambat kinerja otak, sehingga siswa akan kesulitan untuk menyerap informasi yang disampaikan oleh guru selama proses belajar mengajar. Goleman berpendapat: " Orang agaknya dapat berkonsentrasi paling baik saat mereka sedikit lebih dituntut dari biasanya, dan mereka dapat memberikan lebih dari biasanya. Jika tuntutan terlalu sedikit, orang akan menjadi bosan, jika tuntutan terlalu besar untuk diatasi, mereka akan menjadi cemas." (dalam DePorter, 2004). Oleh karena itu, menjadi sangat penting bagi seorang guru untuk dapat menciptakan kondisi fisik maupun mental yang nyaman dan mendukung untuk melakukan aktivitas belajar bagi siswa.

Cara yang dapat dilakukan oleh guru antara lain, melakukan senam otak. Senam otak adalah serangkaian gerakan tubuh yang sederhana yang digunakan untuk memadukan semua bagian otak untuk meningkatkan kemampuan belajar. Senam otak sangat baik dilakukan pada awal proses pembelajaran (Gunawan, 2006).

Gerakan-gerakan senam otak yang sederhana antara lain: (1) Gerakan Silang, yaitu menggerakkan tangan kanan bersamaan dengan kaki kiri dan tangan kiri bersamaan dengan kaki kanan. Bergerak ke depan, ke samping, ke belakang atau jalan di tempat. Sebaiknya tangan menyentuh lutut yang berlawanan; (2) Tidur, yaitu membuat angka 8 tidur tiga kali tiap tangan, kemudian tiga kali dengan kedua tangan. Tidur juga dapat dilakukan dengan menggunakan siku; (3) Coretan Ganda, yaitu menggambar dengan kedua tangan pada saat yang sama, ke dalam, ke luar, ke atas dan ke bawah (4) Putaran Leher, yaitu tundukan kepala ke depan dan pelan-pelan putar leher dari satu sisi ke sisi lainnya. Ulangi dengan bahu diturunkan, serta (5) Mengisi Energi, yaitu duduk di kursi dengan santai dan meletakkan dahi diantara kedua tangan di atas meja. Tarik napas sambil menegakkan kepala, tengkuk dan punggung bagian atas ( Dennison, 2002 ).

Strategi pembelajaran ekspositori adalah strategi pembelajaran yang menekankan pada proses penyampaian materi secara verbal dari seorang guru kepada sekelompok siswa dengan maksud agar siswa dapat menguasai materi pelajaran secara optimal. Roy Killen (1998) dalam Wina Sanjaya manamakan strategi ekspositori ini dengan istilah strategi pembelajaran langsung (Direct Instruction). Pada hakikatnya mengajar menurut stategi pembelajaran ekspositori yaitu menyampaikan ilmu pengetahuan kepada siswa dan siswa dipandang sebagai objek yang menerima apa yang diberikan guru. Guru menyampaikan informasi materi pelajaran dalam bentuk penjelasan dan penuturan secara lisan yang dikenal dengan istilah ceramah.

Menurut Sanjaya (2006) ciri pembelajaran ekspositori adalah pembelajaran yang menekankan kepada proses dan pusat pembelajaran adalah guru, siswa hanya mendengar dan mencatat seperlunya, komunikasi terjadi satu arah dan menyamaratakan kemampuan akademik siswa. Strategi pembelajaran ekspositori umumnya berorientasi pada kegiatan yang berpusat kepada tenaga pengajar (teacher oriented), kebanakan siswa bersifat pasif karena hanya mendengar ceramah dari guru tentang materi yang di sampaikan.

Teori belajar yang mendasari strategi pembelajaran ekspositori adalah teori belajar behavioristik. Kaum behavioris menjelaskan bahwa belajar sebagai suatu proses perubahan tingkah laku dimana reinforcement dan punishment menjadi stimulus untuk merangsang pebelajar dalam berperilaku. Pendidik yang masih menggunakan kerangka behavioristik biasanya merencanakan kurikulum dengan menyusun isi pengetahuan menjadi bagianbagian kecil yang ditandai dengan suatu keterampilan tertentu. Kemudian, bagian-bagian tersebut disusun secara hirarki, dari yang sederhana sampai yang komplek.

Pandangan teori behavioristik telah cukup lama dianut oleh para pendidik. Namun dari semua teori yang ada, teori Skinnerlah yang paling besar pengaruhnya terhadap perkembangan teori belajar behavioristik. Program-program pembelajaran seperti Teaching Machine, Pembelajaran berprogram, modul dan program-program pembelajaran lain 
yang berpijak pada konsep hubungan stimulusrespons serta mementingkan faktor-faktor penguat (reinforcement), merupakan program pembelajaran yang menerapkan teori belajar yang dikemukakan Skinner.

Beberapa karakteristik strategi pembelajaran ekspositori antara lain: (1) cara menyampaikan materi pembelajaran secara verbal, artinya bertutur secara lisan merupakan alat utama dalam melakukan strategi ini, oleh karena itu sering diidentikannya dengan ceramah, (2) biasanya materi pembelajaran yang disampaikan adalah materi pelajaran yang sudah jadi, seperti data atau fakta, konsep-konsep tertentu yang harus dihafal sehingga tidak menuntut siswa untuk berpikir ulang, (3) tujuan utama pembelajaran adalah penguasaan materi pelajaran itu sendiri, dengan kata lain setelah proses pembelajaran berakhir siswa diharapkan dapat memahami dengan benar dengan cara mengungkapkan kembali materi yang telah dipelajari.

Menurut Sanjaya (2008) dalam penggunaan strategi pembelajaran ekspositori terdapat beberapa prinsip yang harus diperhatikan oleh setiap guru antara lain: (1) berorientasi pada tujuan, artinya sebelum melakukan strategi pembelajaran ekspositori guru merumuskan tujuan pembelajaran secara jelas dan terukur yang berorientasi pada kompetensi yang harus dicapai oleh siswa. Hal ini sangat penting, karena dengan tujuan yang jelas memungkinkan guru dapat mengontrol efektivitas penggunaan strategi pembelajaran, (2) prinsip komunikasi, proses pembelajaran dapat dikatakan sebagai proses komunikasi, yang menunjukkan proses penyampaian pesan dari seseorang (sumber pesan) kepada seseorang atau sekelompok orang (penerima pesan). Pesan yang ingin disampaikan dalam hal ini adalah pelajaran yang diorganisir dan disusun sesuai dengan tujuan tertentu. Dalam proses komunikasi guru berfungsi sebagai sumber pesan dan siswa berfungsi sebagai penerima pesan.

Selanjutnya ke 3 prinsip kesiapan, yang artinya setiap individu (siswa) akan merespon dengan cepat dari setiap stimulus manakala dalam dirinya sudah memiliki kesiapan; sebaliknya tidak mungkin setiap individu akan merespon setiap stimulus yang muncul manakala dalam dirinya belum memiliki kesiapan. Agar siswa dapat menerima stimulus yang diberikan, sebelum menerima materi pelajaran peserta didik harus diposisikan dalam keadaan siap baik secara fisik maupun secara psikis untuk menerima pelajaran, (4) prinsip berkelanjutan, dengan pengertian bahwa strategi pembelajaran ekspositori harus dapat mendorong siswa untuk mempelajari materi pelajaran lebih lanjut. Pembelajaran tidak hanya berlangsung pada saat itu, akan tetapi juga untuk waktu selanjutnya. Ekspositori yang berhasil adalah manakala melalui proses penyampaian dapat membawa siswa pada situasi ketidakseimbangan (disequilibrium), sehingga mendorong siswa untuk mencari dan menemukan atau menambah wawasan melalui proses belajar mandiri.

$$
\text { Selanjutnya Sanjaya }
$$

menjelaskan beberapa prosedur pelaksanaan strategi pembelajaran ekspositori antara lain: (1) merumuskan tujuan, sebaiknya dalam bentuk perubahan tingkah laku yang spesifik berorientasi kepada hasil belajar. Melalui tujuan yang jelas selain dapat membimbing siswa dalam menyimak materi juga diketahui efektifitas dan efesiensi strategi ini. (2) menguasai materi dengan baik akan dapat membuat kepercayaan diri guru meningkat, sehingga guru akan mudah mengelola kelas, bebas bergerak, berani menatap siswa, tidak takut dengan perilaku siswa yang mengganggu jalanya proses pembelajaran. Sebaliknya guru yang kurang menguasai materi pelajaran yang akan disampaikan akan kurang percaya diri, sulit bergerak, takut melakukan kontak mata dengan siswa, menjelaskan materi pelajaran serba tanggung dengan suara yang pelan dan miskin ilustrasi. Akibatnya sulit mengatur irama dan iklim pembelajaran dan sulit mengontrol serta mengendalikan perilaku-perilaku siswa. (3) mengenali medan dalam berbagai hal sangat penting diketahui oleh guru seperti: (a) latar belakang siswa yang menerima materi, kemampuan dasar atau pengalaman belajar siswa minat dan gaya belajar dan sebagainya, (b) kondisi ruangan, menyangkut luas dan besarnya ruangan, pencahayaan, posisi tempat duduk, maupun kelengkapan ruangan itu sendiri.

Beberapa langkah penerapan strategi pembelajaran ekspositori yaitu: (1) persiapan (preparation), (2) penyajian (presentation), (3) menghubungkan (correlation), menyimpulkan (generalization), (5) penerapan (aplication). Strategi pengorganisasian pembelajaran melalui strategi ekspositori juga tidak terlepas dari keterbatasan antara lain keunggulan dan kelemahan.

Konsep Locus Of Control pertama kali dikemukakan oleh Jullian Rotter pada tahun 
1966 dimana teori ini merupakan perkembangan dari teori belajar sosial. Locus berasal dari bahasa latin yang artinya "tempat atau lokasi". Rotter menyatakan salah satu faktor individual yang mengendalikan peristiwa kehidupan seseorang adalah Locus Of Control yang ada pada dirinya. Locus Of Control juga memberikan gambaran pada keyakinan seseorang mengenai sumber penentu perilakunya. Ditambahkan pula bahwa Locus of Control adalah suatu cara dimana individu memiliki tanggung jawab terhadap kegiatan yang terjadi dalam control dan diluar control dirinya. Locus of Control merupakan salah satu kepribadian yang didevenisikan sebagai keyakinan terhadap mampu tidaknya mengontrol nasib dirinya. Rotter juga menyimpulkan bahwa kemungkinan perilaku yang muncul pada seseorang didorong oleh dua faktor: (1) Harapan diri ( Personal Ecpectancy), berupa persepsi individu bahwa satu perilaku menghasilkan keuntungan. (2) Nilai dari keuntungan, yaitu jika individu berharap bahwa perilakunya menghasilkan keuntungan yang berharga baginya maka perilaku tersebut akan hilang

Burn (1984), orang yang memiliki Locus Of Control eksternal atau lokus kontrol negatif adalah orang yang mempersiapkan perilaku dan lingkungannya sebagai akibat dari keadaan di luar dirinya, misalnya karena keberuntungan, kesempatan, orang yang berkuasa, otoritas dan sebagainya. Berbagai faktor baik dari dalam maupun dari luar diri seseorang merupakan penyebab terjadinya suatu keberhasilan maupun kegagalan yang diperolehnya..

Main dan Rowe (1993) mengemukakan bahwa Locus Of Control adalah kecenderungan siswa aktif dalam mencari, mengolah dan memanfaatkan berbagai informasi dalam memecahkan masalah karena adanya penghargaan terhadap perilaku atau pengajaran akiabat perilaku itu.

Menurut Goleman (1996) bahwa kesuksesan seseorang 20\% ditentukan oleh IQ dan sekitar $80 \%$ dipengaruhi faktor lain yang meliputi kontrol diri Locus of Control, percaya diri, sikap, empati dan kecerdasan sosial. Hal ini berarti bahwa individu akan sukses apabila lebih percaya diri, sadar akan kemampuan diri sendiri, selalu mengadakan kontrol diri sehingga dapat menyesuaikan dengan situasi dan kondisi dimana dia berada termasuk meraih prestasi.

Locus Of Control dapat dibedakan menjadi dua yaitu : locus of contol internal dan eksternal. Orang yang memiliki Locus Of Control internal adalah orang yang memandang penguatan (reinforcement) yang diterimanya sebagai hasil usaha, kemampuan dan karakter diri yang dimilikinya. Sedangkan orang yang memiliki Locus of Control eksternal adalah orang yang merasakan atau memandang penguatan ( rienforcement) yang diterimanya adalah fungsi dari kekuatan yang berada diluar jangkauan pemikiran dan penguasaanya seperti : nasib, takdir atau kondisi dan situasi tertentu yang tidak dapat dihindarinya.

Menurut Rotter (1996) pembagian Locus Of Control seseorang apakah tergolong dalam Locus of Control internal ataupun eksternal dapat dilakukan melalui pengujian berupa tes yang harus dijawab oleh orang tersebut. Rotter sendiri telah menyusun suatu tes Locus Of Control berupa pertanyaan-pertanyaan positif maupun negatif yang harus dijawab oleh responden, berdasarkan skor yang diurutkan maka dilakukan analisis dengan ketentuan apabila skor tertinggi diperoleh dari pernyataan negatif, maka dikelompokkan dalam Locus $O f$ Control negatif sedangkan apabila skor tertinggi diperoleh dari pernyataan positif maka dapat dikelompokkan dalam Locus Of Control positif.

Sependapat dengan Rotter, Yeani, Dost dan Matthews (1980) juga mengemukakan bahwa Locus Of Control ada dua jenis yaitu Locus Of Control internal dan Locus Of Control eksternal. Siswa yang memiliki Locus Of Control internal mempunyai sifat yang lebih aktif dalam mencari, mengolah dan mendapatkan berbagai informasi serta memiliki keinginan untuk mencapai prestasi yang lebih tinggi, memiliki rasa percaya diri yang tertinggi, kemauan bekerja keras. Memiliki kemampuan kemauan dan kemampuan mengikuti penjelasan guru tentang isi dan materi yang dipelajari, memiliki kemauan dan kemampuan mempelajari berbagai sumber yang barkaitan dengan materi pelajaran yang diikuti.

Dari uraian tersebut dapat disimpukan Locus Of Control merupakan salah satu unsur kepribadian manusia yang mencerminkan pandangan, tanggapan dan penilaian seseorang atas dirinya. Hal ini berarti bahwa individu akan sukses apabila lebih percaya diri, sadar akan kemampuan yang dimiliki, selalu mengadakan kontrol diri, sehingga dapat menyesuaikan dengan situasi dan kondisi dimana dia berada termasuk meraih prestasi.

Rumusan masalah sebagai berikut: (1) Apakah hasil belajar ekonomi siswa yang 
diajarkan dengan strategi pembelajaran Berbasis Genius Learning lebih tinggi dibandingkan hasil belajar ekonomi yang diajarkan dengan strategi pembelajaran Ekspositori?; (2) Apakah hasil belajar ekonomi siswa yang memiliki Locus $O f$ Control internal lebih tinggi dibandingkan dengan hasil belajar ekonomi siswa yang memiliki Locus Of Control eksternal?; dan (3) Apakah terdapat interaksi antara strategi pembelajaran dengan Locus Of Control dalam mempengaruhi hasil belajar ekonomi siswa?

\section{METODE}

Penelitian ini dilaksanakan di kelas $\mathrm{X}$ (sepuluh) SMA Methodis1 dan SMA Kalam Kudus Medan. Populasi penelitian ini adalah seluruh siswa kelas $\mathrm{X}$ (sepuluh) SMA Methodist 1 dan SMA Kalam Kudus Medan pada semester genap tahun ajaran 2011/2012 yang aktif sekolah yang terdiri dari 6 kelas yaitu 3 kelas SMA Methodist 1 dan 3 kelas SMA
Kalam Kudus dengan jumlah keseluruhan sebanyak 210 orang. Sampel penelitian diperoleh dengan menggunakan cara cluster random sampling atau teknik pengambilan sampel secara acak sebanyak satu kelas di SMA Methodist 1 dan 1 kelas SMA Kalam Kudus .

Penelitian ini menggunakan metode eksperimen semu (quasi-experiment) dengan rancangan faktorial $2 \times 2$. Untuk memperoleh data hasil belajar digunakan instrumen tes hasil belajar dan kuesioner yang telah diuji validitas dan reliabilitasnya. Sementara untuk memperoleh data Locus Of Control internal dan eksternal yang kemudian dilakukan uji persyaratan analisis yaitu uji Lilliefors untuk normalitas dan uji Bartlett untuk homogenitas data. Data yang diperoleh dianalisis dengan ANAVA 2 jalur dengan uji $F$ pada taraf signifikansi $\alpha=0,05$.

Rancangan penelitian ini dapat di lihat pada tabel dibawah ini:

Tabel 1. Desain Penelitian

\begin{tabular}{|c|c|c|}
\hline Strategi Pembelajaran $(\mathrm{A})$ & $\begin{array}{c}\text { Berbasis Genius } \\
\text { Learning }\left(\mathrm{A}_{1}\right)\end{array}$ & Ekspositori $\left(\mathrm{A}_{2}\right)$ \\
\hline Locus Of Control $(\mathrm{B})$ & $\left(\mathrm{A}_{1} \mathrm{~B}_{1}\right)$ & $\left(\mathrm{A}_{2} \mathrm{~B}_{1}\right)$ \\
\hline
\end{tabular}

$$
\text { Eksternal }\left(\mathrm{B}_{2}\right)
$$

Keterangan:

$\mathrm{A}_{1} \mathrm{~B}_{1}=$ Hasil belajar siswa yang diajarkan dengan menggunakan strategi Genius Learning memiliki Locus Of Control internal

$\mathrm{A}_{1} \mathrm{~B}_{2}=$ Hasil belajar siswa yang diajarkan dengan menggunakan strategi Berbasis Genius Learning memiliki Locus Of Control eksternal

$\mathrm{A}_{2} \mathrm{~B}_{1}=$ Hasil belajar siswa yang diajarkan dengan menggunakan strategi Ekspositori memiliki Locus Of Control internal

$\mathrm{A}_{2} \mathrm{~B}_{2}=$ Hasil belajar siswa yang diajarkan dengan menggunakan strategi Ekspositori memiliki Locus Of Control eksternal

Untuk menguji hipotesis penelitian digunakan teknik analisi data dengan analisis varian (ANAVA) dua jalur dengan taraf signifikan 0,05. Untuk menggunakan ANAVA dua jalur perlu dipenuhi beberapa persyaratan, yaitu: 1) data yang digunakan harus berdistribusi normal, maka dilakukan uji normalitas dengan
(Aeliggunakan uji Liliefors, $\left(\mathrm{A} \mathrm{An}_{2} \mathrm{~B} 2\right)$ data harus memiliki varians populasi yang homogen maka harus dilakukan uji homogenitas varians dengan menggunkan uji Bartlett.

Setelah melakukan pengujian persyaratan analisi, selanjutnya dilakukan pengujian anava 2 jalur. Jika anava 2 jalur signifikan maka diadakan uji lanjut (post hoc test). Uji lanjut akan dilakukan dengan uji Tuckey jika jumlah sampel sama besar (n sama), tetapi jika jumlah sampel tiap sel tidak sama (n tidak sama) maka akan digunakan uji scheffe. Selanjutnya untuk pengujian hipotesi, dirumuskan hipotesis statistik seperti berikut :

Hipotesis $1=$ Ho $: \mu \mathrm{A}_{1}=\mu \mathrm{A}_{2}$ $\mathrm{Ha}: \mu \mathrm{A} 1>\mu \mathrm{A} 2$

Hipotesis $2=$ Ho $: \mu B_{1}=\mu B_{2}$ $\mathrm{Ha}: \mu \mathrm{B} 1>\mu \mathrm{B} 2$

Hipotesis $3=$ Ho : $\mathrm{A} \times \mathrm{B}=0$

$$
=\mathrm{Ha}: \mathrm{A} \times \mathrm{B} \neq 0
$$

\section{HASIL DAN PEMBAHASAN \\ Hasil}


Berdasarkan data skor tes hasil belajar tabel anava, seperti pada tabel 2. berikut: ekonomi siswa dari tiap kelompok perlakuan menurut

\begin{tabular}{|c|c|c|c|c|c|c|}
\hline \multirow[b]{2}{*}{$\begin{array}{l}\text { Locus Of Control } \\
\text { (B) }\end{array}$} & \multicolumn{4}{|c|}{ STRATEGI Pembelajaran (A) } & \multirow{2}{*}{\multicolumn{2}{|c|}{ Total }} \\
\hline & \multicolumn{2}{|c|}{$\begin{array}{c}\text { STRATEGI } \\
\text { GENIUS } \\
\text { LEARNING (A1) }\end{array}$} & \multicolumn{2}{|c|}{$\begin{array}{c}\text { STRATEGI } \\
\text { EKSPOSITORI } \\
\text { (A2) }\end{array}$} & & \\
\hline \multirow{4}{*}{$\begin{array}{c}\text { LOCUS OF } \\
\text { CONTROL } \\
\text { INTERNAL (B1) }\end{array}$} & $\mathrm{N}=$ & & $\mathrm{N}=$ & & $\mathrm{N}=$ & 35 \\
\hline & $\sum X=$ & 469 & $\sum X=$ & 515 & $\sum X=$ & 984 \\
\hline & $\sum X^{2}=$ & 14345 & $\sum X^{2}=$ & 14475 & $\sum X^{2}=$ & 28820 \\
\hline & $\bar{X}=$ & 29,3125 & $\bar{X}=$ & 29,23529 & $\bar{X}=$ & 58,28529 \\
\hline \multirow{4}{*}{$\begin{array}{c}\text { LOCUS OF } \\
\text { CONTROL } \\
\text { EKSTERNAL (B2) }\end{array}$} & $\mathrm{N}=$ & & $\mathrm{N}=$ & 17 & $\mathrm{~N}=$ & 37 \\
\hline & $\sum X=$ & 561 & $\sum X=$ & 514 & $\sum X=$ & 1075 \\
\hline & $\sum X^{2}=$ & 16339 & $\sum X^{2}=$ & 16070 & $\sum X^{2}=$ & 32409 \\
\hline & $\bar{X}=$ & 27,10526 & $\bar{X}=$ & 28,05 & $\bar{X}=$ & 56,41776 \\
\hline \multirow{4}{*}{ Total } & $\mathrm{N}=$ & & $\mathrm{N}=$ & & $\mathrm{N}=$ & \\
\hline & $\sum X=$ & 1030 & $\sum X=$ & 1029 & $\sum X=$ & 2059 \\
\hline & $\sum X^{2}=$ & 30684 & $\sum X^{2}=$ & 30545 & $\sum X^{2}=$ & 61229 \\
\hline & $\bar{X}=$ & 57,3625 & $\bar{X}=$ & 56,34056 & $\bar{X}=$ & 114,7031 \\
\hline
\end{tabular}

Secara keseluruhan hasil Anava untuk pengujian hipotesis dapat dilihat pada tabel 3 dibawah ini :

\begin{tabular}{|c|c|c|c|c|c|c|}
\hline Sumber Varians & JK & $\mathrm{dk}$ & RJK & F hitung & Ftabel & Kesimpulan \\
\hline Strategi Pembelajaran & 38,89 & 1 & 38,89 & 4,21 & \multirow{3}{*}{3,98} & Signifikan \\
\hline Locus Of Control & 58,847 & 1 & 58,847 & 6,81 & & Signifikan \\
\hline Interaksi & 2331,4209 & 1 & 2331,421 & 70,61 & & Signifikan \\
\hline Antar Kelompok & 102,08365 & 3 & & & & \\
\hline Dalam Kelompok & 2245,2358 & 68 & & & & \\
\hline Total & 4776,4773 & & & & & \\
\hline
\end{tabular}

Karena ada interaksi antara strategi pembelajaran dan Locus of control dalam mempengaruhi hasil belajar ekonomi, maka perlu dilakukan uji lanjutan (post hoc test) untuk mengetahui rata-rata hasil belajar sampel mana yang berbeda. Untuk melihat bentuk interaksi antara strategi pembelajaran dan Locus of control dalam mempengaruhi hasil belajar ekonomi, dilakukan uji lanjut dengan menggunakan uji scheffe. Ringkasan hasil uji Scheffe dapat dilihat pada tabel 4. berikut :

\begin{tabular}{|c|c|c|c|}
\hline \multicolumn{2}{|c|}{ Hipotesis Statistik } & F hitung & F tabel \\
\hline Ho $: \mu_{A 1 B 1}=\mu_{A 2 B 1}$ & Ha $: \mu_{A 1 B 1}>\mu_{A 2 B 1}$ & 5,80633 & \\
\cline { 1 - 2 } Ho $: \mu_{A 1 B 1}=\mu_{A 1 B 2}$ & $\mathrm{Ha}: \mu_{A 1 B 1}>\mu_{A 1 B 2}$ & 3,3988 & \\
\cline { 1 - 2 } Ho $: \mu_{A 1 B 1}=\mu_{A 2 B 2}$ & $\mathrm{Ha}: \mu_{A 1 B 1}<\mu_{A 2 B 2}$ & 2,3036 & \multirow{2}{*}{2,74} \\
\cline { 1 - 2 } Ho $: \mu_{A 2 B 1}=\mu_{A 1 B 2}$ & $\mathrm{Ha}: \mu_{A 2 B 1}>\mu_{A 1 B 2}$ & 2,7879 & \\
\cline { 1 - 2 } Ho $: \mu_{A 2 B 1}=\mu_{A 2 B 2}$ & $\mathrm{Ha}: \mu_{A 2 B 1}>\mu_{A 2 B 2}$ & 8,5054 & \\
\cline { 1 - 2 } Ho $: \mu_{A 2 B 2}=\mu_{A 1 B 2}$ & $\mathrm{Ha}: \mu_{A 2 B 2}>\mu_{A 1 B 2}$ & 6,08183 & \\
\hline
\end{tabular}


Selanjutnya adanya interaksi antara variabel strategi pembelajaran dan locus of control terhadap hasil belajar ekonomi siswa, maka perlu diberikan gambaran grafik estimasi yang menunjukkan adanya interaksi tersebut.

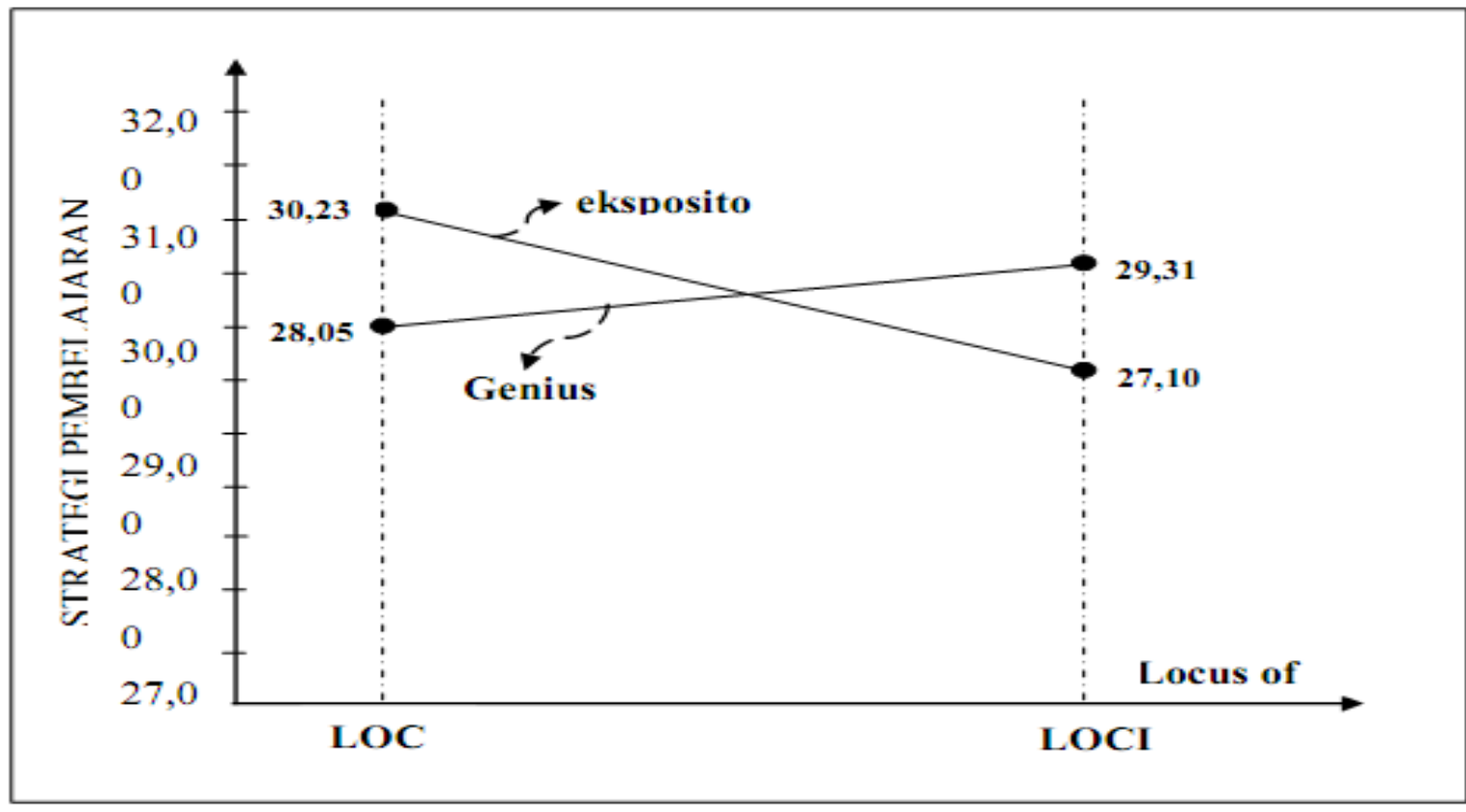

Gambar 1. Interaksi Antara Strategi Pembelajaran Dan Locus Of Control Terhadap Hasil Belajar Ekonomi Siswa

\section{Pembahasan}

Hasil penelitian ini telah menunjukkan bahwa hasil belajar Ekonomi siswa yang diajar dengan strategi pembelajaran Berbasis Genius Learning lebih tinggi dibandingkan dengan strategi pembelajaran Ekspositori. Suasana kelas ketika proses pembelajaran, inti dari strategi pembelajaran Berbasis Genius Learning adalah menciptakan suasana yang menyenangkan untuk belajar sehingga siswa merasa nyaman untuk belajar dan lebih mudah menyerap informasi. Dalam strategi pembelajaran Berbasis Genius Learning guru mencoba menciptakan suasana kelas yang menyenangkan misalnya dengan melakukan senam otak sebelum belajar, mengiringi pembelajaran dengan musik, menata ruangan menjadi lebih rapi dan apik dengan tempelan-tempelan gambar edukatif dan afirmasi positif. Dengan suasana kelas yang menyenangkan diharapkan siswa akan menjadi lebih termotivasi untuk belajar dan mudah menangkap dan mencerna informasi yang dipelajari.

Dilihat dari segi prosedur strategi pembelajaran Berbasis Genius Learning terdiri dari delapan tahapan yang terdiri dari suasana kondusif, hubungkan, gambaran besar, tetapkan tujuan, pemasukan informasi, aktivasi, demonstrasi serta tinjau ulang dan jangkarkan. Kedelapan tahapan tersebut dapat dibagi menjadi 3 bagian besar, yaitu pembuka (suasana kondusif, hubungkan, gambaran besar dan tetapkan tujuan), isi (pemasukan informasi) dan penutup (aktivasi, demonstrasi serta tinjau ulang dan jangkarkan). Berbasis Genius Learning sangat mementingkan bagian pembuka dan penutup dari proses pembelajaran dan memberikan porsi lebih. Dalam strategi ini, pembuka dan penutup adalah hal yang penting, dalam bagian pembuka, guru harus benar-benar mempersiapkan siswa dalam keadaan siap untuk menerima pelajaran. Untuk mendapatkannya, yang pertama harus merasa nyaman dengan suasana belajar, kemudian siswa mengetahui untuk apa ia mempelajari materi tersebut, gambaran besarnya seperti apa dan menetapkan tujuan yang ingin dicapai diakhir pembelajaran. Sehingga di awal pembelajara siswa sudah benar-benar mempersiapkan dan merencanakan kegiatan belajarnya. Hal ini akan menjadikan kegiatan belajar lebih terarah dan bermakna. Sedangkan di akhir pelajaran, strategi pembelajaran Berbasis Genius Learning menekankan pada proses pengulangan dan umpan balik yang segera. Proses aktivasi dan demonstrasi adalah proses dimana siswa menguji 
dan menunjukkan penguasaannya terhadap materi yang baru dipelajari. Pada tahap ini guru memberikan umpan balik langsung terhadap pekerjaan siswa dan kemudian langkah terakhir siswa menarik kesimpulan terhadap apa yang telah dipelajari.

Pelajaran Ekonomi memiliki cakupan yang sangat luas, sehingga proses pembelajaran harus memberikan kesempatan kepada siswa untuk menanggapi bahan pelajaran secara kritis, analitis agar nilai-nilai yang terkandung dalam mata diklat Ekonomi betul-betul dipahami dan diyakini oleh siswa. Untuk itu, guru diharapkan memiliki pengetahuan dan pemahaman mengenai strategi pembelajaran, sebab pengetahuan dan pemahaman mengenai strategi pembelajaran sangat penting sebagai salah satu upaya dalam memberikan pengalaman dan pencapaian tujuan belajar yang optimal guru dituntut untuk meningkatkan mutu pembelajaran dan harus memperhatikan hakikat, tujuan mata pelajaran yang akan diajarkan, serta mempertimbangkan karakteristik siswa. Hal ini sesuai dengan pendapat Purwanto (2007) bahwa dalam belajar di sekolah, faktor guru dan cara mengajarnya menrupakan faktor yang sangat penting. Artinya, penguasaan guru terhadap strategi pembelajaran sangat diperlukan untuk meningkatkan kemampuan profesional guru dalam mengajar, oleh sebab itu guru harus dapat menentukan strategi yang paling tepat dan sesuai dengan tujuan serta materi yang akan disampaikannya. Strategi Genius Learning merupakan suatu strategi yang digunakan untuk menuntut siswa secara aktif mampu memahami pelajaran untuk meningkatkan hasil belajar ekonomi. Dalam melaksanakan strategi pembelajaran guru mengarahkan siswa bukan hanya sebagai pendengar, tetapi belajar untuk menemukan dan mencari sendiri selayaknya ilmuan.

Sedangkan pada pembelajaran Ekspositori, proses pembelajaran lebih didominasi oleh guru, walaupun tidak sebesar yang ada pada ceramah, namun tugas guru dalam strategi ini adalah menjalankan pokok-pokok materi dalam waktu yang terbatas, memberi informasi yang kemudian diselingi dengan metode diskusi, latihan mengerjakan soal, dan diselingi dengan penjelasan dari guru secara klasikal atau kelompok sewaktu siswa lain mengerjakan tugasnya. Peranan guru dalam strategi Ekspositori adalah sebagai pembimbing program, pemberi informasi, dan pemindah sumber pengajaran. Dalam Ekspositori ini biasanya pembelajaran terpusat pada guru. Para siswa kurang aktif, dan kurang diarahkan untuk menemukan informasi sendiri terutama yang dapat diperoleh dari lingkungan sekitar dirinya, padahal mata diklat Ekonomi sangat erat dengan masalah-masalah di lingkungan sekitar khususnya dalam mencari dan menciptakan peluang usaha. Siswa berperan sebagai pengikut petunjuk guru, pembaca materi, mengerjakan tugas, mendiskusikan topik yang sedang dibahas. Strategi ini mengurangi kreativitas siswa dan kecerdasan dalam berpikir untuk memecahkan masalah-masalah dalam pembelajaran Kewirausahaan. Di samping itu juga tidak terbentuknya sikap kritis, mandiri dan selalu bergantung dengan apa yang disampaikan dan diperintahkan oleh guru.

Strategi pembelajaran Ekspositori merupakan pendekatan pembelajaran yang berorientasi pada guru, artinya guru merupakan satu-satunya sumber informasi dan pengetahuan siswa (teacher centre). Strategi pembelajaran ini berorientasi pada guru dan biasanya ceramah menjadi pilihan utama metode pembelajarannya. Lebih lanjut Davies (1991:233) mengatakan "biasanya pelajar tidak mempunyai banyak kesempatan untuk memberi tanggapan". Peserta didik lebih dominan pasif dan tidak berpartisipasi aktif dalam kegiatan pembelajaran. Kondisi seperti ini akan mengakibatkan siswa kurang diberdayakan dalam menemukan ilmu pengetahuan yang dibutuhkannya, sehingga siswa memperoleh ilmu dan pengetahuan tersebut berdasarkan apa yang disampaikan oleh gurunya saja.

Karakteristik strategi pembelajaran secara ekpositori adalah dilakukan oleh guru dengan cara menyampaikan materi pelajaran secara verbal, artinya bertutur secara lisan merupakan alat utamanya karena itu sering diidentikan dengan ceramah, biasanya materi pelajaran yang disampaikan adalah materi pelajaran yang sudah jadi, seperti data atau fakta konsep-konsep tertentu yang harus dihafal sehingga tidak menuntut siswa untuk berpikir ulang, tujuan utama pembelajaran adalah penguasaan materi pelajaran itu sendiri. Artinya, setelah proses pembelajaran berakhir siswa diharapkan dapat memahaminya dengan benar dengan cara dapat mengungkapkan kembali materi yang telah diuraikan. Strategi pembelajaran Ekspositori merupakan bentuk dari pendekatan pembelajaran yang berorientasi kepada guru.

Selanjutnya Dick and Carey (2005) mengemukakan bahwa strategi pembelajaran 
Ekspositori cenderung menggunakan hapalanhapalan dan lebih mengarah ke aspek memorization, yang menitik beratkan unsur ingatan, sehingga siswa memperoleh pengetahuan dan keterampilan dangan cara menghubungkan kata-kata dengan subjek secara berulang-ulang, yang pada akhirnya bila siswa belum hapal dengan sempurna, maka materi tersebut tidak dapat diteruskan atau ditambah. Dalam strategi pengorganisasian ini, guru yang lebih banyak berperan, artinya siswa tidak terlibat secara langsung dalam mencari dan menemukan materimateri penting dari suatu proses pembelajaran, sehingga pengetahuan dan keterampilan yang diperoleh tidak mampu meningkatkan retensi dan daya ingat siswa, atau hanya berada dalam memori ingatan jangka pendek saja. Akhirnya, keberhasilan siswa dalam belajar amat tergantung pada penyampaian guru, kemampuan, dan pengalaman guru saja. Pembelajaran seperti ini akan berpotensi untuk memberikan perolehan hasil belajar yang kurang maksimal. Strategi pembelajaran berdasarkan Ekspositori tidak mendorong tumbuhnya rasa keingintahuan dan rasa tanggungjawab siswa dalam merencanakan dan mengorganisasikan cara belajarnya. Akibatnya, pengetahuan dan keterampilan yang dimiliki siswa hanya berada pada ingatan jangka pendek saja, dan akan cenderung tidak mampu dalam meningkatkan daya retensi siswa terhadap materi pelajarannya. Dalam pembelajaran tersebut komunikasi yang berlangsung dalam proses pembelajaran satu arah, maka cenderung menimbulkan kesalahpamahaman siswa terhadap konsep-konsep dan istilah tertentu,

Kelompok Locus of Control eksternal lebih rentan ketika manghadapi kegagalan, karena mereka bisa kehilangan harga diri dan kepercayaan dirinya manakala tugas atau pekerjaan yang diberikan tidak dapat diselesaikan atau hasil dari tugas atau pekerjaan yang telah diselesaikan tidak sesuai dengan harapan. Mereka cenderung menimpakan kegagalannya kepada dirinya dan bisa menyebabkan luka yang mendalam dan bisa permanen. Individu dengan Locus of Control eksternal juga memiliki motivasi lemah, karena mereka sering menyandarkan segala sesuatu pada nasib, bersandar pada kejadian-kejadian diluar kendalinya dan sering berpendapat untuk apa bersusah payah dalam mencapai sesuatu yang pada akhirnya juga akan ditentukan oleh nasib. Akibatnya daya juang individu dengan Locus of Control eksternal dan mudahmenyerah.
Perbedaan dalam kecenderungan Locus of Control internal dan eksternal berhubungan dengan bentuk kontrol terhadap lingkungan. Individu yang berorentasi internal lebih aktif dan selalu berusaha menguasai kehidupan yang dijalaninya dibandingkan dengan individu yang berorentasi eksternal (Rotter, 1996). Menurut Penner (dalam Cooper dan Payne, 1991) individu dengan orientasi internal mempunyai pandangan dunia yang berbeda dengan individu yang berorentasi eksternal.

Temuan penelitian menunjukkan bahwa terdapat interaksi antara strategi pembelajaran dan Locus of Control terhadap hasil belajar ekonomi. Siswa yang memiliki Locus of Control internal memiliki hasil belajar yang lebih tinggi daripada siswa yang memiliki Locus of Control eksternal yang diajarkan dengan menggunakan strategi pembelajaran Genius Learning, demikian pula halnya dengan siswa yang memiliki Locus of Control eksternal memiliki hasil belajar yang lebih tinggi daripada siswa yang memiliki Locus of Control internal pada kelas yang diberi strategi pembelajaran Ekspositori. Hal ini mengindikasikan adanya interaksi antara penggunaan strategi pembelajaran dengan Locus of Control terhadap hasil belajar ekonomi siswa.

Strategi pembelajaran Berbasis Genius Learning merupakan rangkaian pendekatan praktis dalam upaya meningkatkan hasil pembelajaran. Upaya peningkatan ini dicapai dengan menggunakan pengetahuan yang berasal dari berbagai disiplin ilmu seperti pengetahuan tentang tata cara kerja otak, cara kerja memori, neurolinguistik programming, motivasi, konsep diri, kepribadian, emosi, perasaan, pikiran, metakognisi, gaya belajar, multiple intellegence, teknik memori, teknik membaca, teknik mencatat dan teknik belajar lainnya. Dalam strategi pembelajaran Genius Learnimg sangat diharapkan siswa secara aktif agar dapat memecahkan masalah baik secara aktif dapat memecahkan masalah baik secara mandiri maupun secara bersama-sama dalam diskusi secara klasikal dan mampu berfikir bebas.

Strategi pembelajaran Ekspositori adalah strategi pembelajaran yang lebih menekankan penyampaian informasi melalui verbal, tidak terlalu banyak aktivitas kelas dan tidak menuntut siswa untuk berperan aktif. siswa dengan Locus Of Control eksternal mungkin akan merasa lebih nyaman dengan suasana monoton dan tidak terlalu banyak menuntut aktivitas di kelas, tampil di depan guru dan siswa 
lain. Beberapa karakteristik strategi pembelajaran ekspositori antara lain: (1) cara menyampaikan materi pembelajaran secara verbal, artinya bertutur secara lisan merupakan alat utama dalam melakukan strategi ini, oleh karena itu sering diidentikannya dengan ceramah, (2) biasanya materi pembelajaran yang disampaikan adalah materi pelajaran yang sudah jadi, seperti data atau fakta, konsepkonsep tertentu yang harus dihafal sehingga tidak menuntut siswa untuk berpikir ulang, (3) tujuan utama pembelajaran adalah penguasaan materi pelajaran itu sendiri, dengan kata lain setelah proses pembelajaran berakhir siswa diharapkan dapat memahami dengan benar dengan cara mengungkapkan kembali materi yang telah dipelajari.

Siswa dengan Locus of Control eksternal cenderung merasa tidak mampu melakukan apa-apa, merasa lebih bodoh dibandingkan teman-temannya, dan tidak percaya diri, sehingga akan lebih nyaman baginya jika aktivitas kelas tidak menuntut peran sertanya, tidak melakukan aktivitas yang mengharuskannya tampil di kelas dan sebagainya. Sehingga siswa dengan Locus Of Control eksternal mungkin akan memperoleh hasil belajar yang lebih tinggi jika belajar dengan strategi pembelajaran

\section{PENUTUP \\ Simpulan}

Hasil belajar ekonomi siswa dengan strategi pembelajaran Berbasis Genius Learning lebih baik dibandingkan dengan strategi pembelajaran ekspositori. Dalam hal ini siswa yang dibelajarkan dengan menggunakan strategi pembelajaran Berbasis Genius Learning lebih baik dibandingkan dengan hasil belajar siswa yang dibelajarkan dengan strategi pembelajaran ekspositori.

Hasil belajar siswa yang memiliki Locus

Of Control Internal lebih baik dibandingkan dengan hasil belajar siswa yang memiliki Locus Of Control Eksternal. Dengan demikian siswa yang memiliki Locus of Control Internal memperoleh hasil belajar ekonomi yang lebih baik dibandingkan dengan siswa yang memiliki Locus Of Control Eksternal.

Terdapat interaksi antara strategi pembelajaran Berbasis Genius Learning dan Locus Of Control dalam mempengaruhi hasil belajar Ekonomi. Untuk siswa yang memiliki Locus Of Control Internal akan lebih efektif dalam meningkatkan hasil belajar Ekonomi jika menggunakan strategi pembelajaran Berbasis Genius Learning, sedangkan untuk siswa yang memiliki Locus of Control Eksternal lebih efektif dalam meningkatkan hasil belajar Ekonomi dengan menggunakan strategi pembelajaran ekspositori.

\section{Saran}

Berdasarkan hasil penelitian, simpulan, dan keterbatasan penelitian, maka dikemukakan saran-saran sebagai berikut:

1. Guru perlu memperhatikan karakteristik siswa, karena Locus of Control yang merupakan aspek kognitif memberikan pengaruh yang besar terhadap hasil belajar siswa.

2. Untuk membelajarkan materi yang lebih praktis pada belajar Ekonomi, hendaknya alokasi waktu yang dibutuhkan lebih banyak, sehingga siswa dapat mengaplikasikan ilmunya untuk kegiatan-kegitan yang nyata, sehingga bidang studi ini lebih membumi dalam struktur kognisi mereka.

3. Oleh strategi pembelajaran Berbasis Genius Learning sesuai dan sangat menolong siswa yang memiliki Locus of Control Internal dalam meningkatkan hasil belajar Ekonomi, maka disarankan khususnya pada para guru Ekonomi untuk menggunakannya dalam membelajarkan Ekonomi.

4. Dikarenakan tes hasil belajar yang disusun hanya mengukur ranah kognitif, sebaiknya penelitian lanjutan juga mengukur ranah psikomotorik.

5. Karakteristik siswa yang dijadikan variabel moderator dalam penelitian ini adalah Locus of Control. Disarankan untuk penelitian lanjut, melibatkan karakteristik siswa yang lain guna melengkapi kajian penelitian ini, seperti minat, bakat, tingkat kreativitas, dan lain sebagainya.

\section{DAFTAR PUSTAKA}

Atmadi, A dan Y. Setyaningsih. 2000. Transformasi Pendidikan Memasuki Millenium Ketiga, Yogyakarta: Kanisius.

Arikunto, Suharsimi. 2005. Manajemen Penelitian, Jakarta: Rineka Cipta.

Arikunto, Suharsimi. 2003. Dasar-Dasar Evaluasi Pendidikan, Jakarta: Bumi Aksara

Berliner, Gage. 1984. Educational Psycology, London: Houghton Mifflin Company

Bigge, Morris L. 1982. Learning Theories For Teachers. New York: Harper \& Row 
Charles, C.M. 1980. Individualizing Instruction, London: Mosby Company

Dennison, Paul E. dan Dennison, Gail E. 2002. Braim Gym, Jakarta: Gramedia Widiasarana Indonesia.

DePorter, B., Reardon, M., dan Sarah, S. 2004. Quantum Teaching, Bandung: Kaifa.

DePorter, B. 2004. Quantum Learning, Bandung: Kaifa.

Dick, W \& Carey, L. 2005. The Systematic Design of Instrustional. New York: Longman

Fajar, Arnie. 2004. Portofolio dalam pembelajaran IPS, Bandung: PT. Remaja Rosdakarya.

Gagne, Robert M \& Driscoll, Marcy P. 1989. Essentials of Learning for Instruction. New Jersey: Prentice Hall

Gerlach, Vernon S \& Ely, Donald P. 1980. Teaching \& Media, A Systematic Approach. New Jersey: Prentice Hall

Given, Barbara K. 2007. Brain Based Teaching. Bandung: Kaifa Gulo, W.

Gunawan, Adi W. 2006. Berbasis Genius Learning Strategy, Jakarta: Gramedia Pustaka Utama.

Gunawan, Adi W. 2004. Born to be a Genius, Jakarta: Gramedia Pustaka Utama.

Jarolimek, John \& Foster, Clifford D. 1976. Teaching and Learning in the Elementary School. London: Macmillan

Linksman, Ricki. 2004. Cara Belajar Cepat, Semarang: Dahara Prize.

MacGregor, Sandy. 2005. Piece of Mind, Jakarta: Gramedia Pustaka Utama.
Madden, Thomas L. 2002. Fire Up Your Learning, Jakarta: Gramedia Pustaka Utama.

Miarso, Yusufhadi. 2007. Menyemai Benih Teknologi Pendidikan. Jakarta: Kencana

Milfayetty, Sri dan Anita Yus. 2005. Pengentasan Masalah Belajar Melalui Strategi Berbasis Genius Learning, Medan: Yayasan Refleksi Pendidikan.

Muijs, Daniel \& Reynolds, David. 2008. Effective Teaching. Yogyakarta: Pustaka Pelajar

Owie, T. W. Locus of Control, Intructional Mode and Student achievement. Instructional Science

Prawiradilaga, Dewi Salma. 2008. Prinsip Disain Pembelajaran. Jakarta: Kencana

Romizwoski, A.J. 1981. Instructional Design System, Decision Making in Course Planning and Curriculum Design. London: Kogan

Rose, Colin dan Malcolm J. Nicholl. 2002. Accelerated Learning For The $21^{\text {St }}$ Century, Bandung: Nuansa.

Sanjaya, Wina. 2008. Strategi Pembelajaran. Jakarta: Kencana

Silberman, Mel. 2000. Active Learning, Yogyakarta: Yappendis.

Suchman, J. Richard. 1966. Developing Inquiry. IIlinois-USA: Science Research Associetes.

Sukirno, Sadono. 2005. Mikro Ekonomi Teori Pengantar. Jakarta: RajaGrafindo Persada

Syah, Muhibbin. 2008. Psikologi Belajar. Jakarta: RajaGrafindo Persada 